\title{
Impact of Corruption and Crime on Smuggling: Evidence from Iran
}

\author{
Amin Mansouri \& Morteza Afghah \\ Shahid Chamran University of Ahvaz, Iran \\ sa.mansouri@scu.ac.ir \\ DOI: https://doi.org/10.32890/jis2019.15.4
}

Received: 30/10/2018

Revised: $27 / 7 / 2019$

Accepted: 1/10/2019

Published: 5/9/2019

\begin{abstract}
The main purpose of this research is to investigate the size and the relationship between smuggling and crime indexes such as returned checks, corruption and drinking alcohol in Iran during the period 1984-2015 by using Multiple Indicators Multiple Causes (MIMIC) model and Maximum Likelihood Estimation (MLE) method. The results showed that among the crime indexes, divorce, drinking alcohol and corruption were positively correlated with smuggling, while another crime index, returned checks had a negative relationship with smuggling. Besides, all socio-economic cause variables on smuggling, including tariffs, misery index, illiteracy, gap of exchange rate, economic openness index and the size of government were found to increase smuggling. Furthermore, the findings showed that the cause variables on smuggling, including liquidity and energy consumption were positively correlated with smuggling.
\end{abstract}

Keywords: Crime, misery index, illiteracy, corruption, MIMIC, smuggling.

\section{Introduction}

High crime rates and associated social disorders are considered to be among the most complicated issues in most urban areas worldwide, as they create a sense of public insecurity and impose financial burdens on society, the government and judicial system on the one hand; and change the ethical atmosphere of the society on the other. Existing statistics have revealed that solutions such as enlarging police forces, taking stricter security measures, imposing more severe punishment as well as constructing more prisons do not prove to be effective deterrents. This unpleasant phenomenon is usually considered regardless of the local, social, economic and cultural conditions which influence criminals. Nevertheless, to combat crime and social wrongdoings, crime-inducing factors and their interrelationship with the different kinds of crime need to be carefully identified. It is believed that through eradicating such factors or diluting their effects, the incidence of crime can be prevented or at least reduced. 
Accordingly, crime is considered as an undesirable social phenomenon that investigation of its causes has attracted the attention of economists since the late 1960s. One of the earliest studies on the economic background of crime was by Fleisher (1963). By examining the relationship between crime and unemployment, he concluded that there was a direct relationship between crime rate and unemployment (Fleisher, 1963). The relationship between poverty and unemployment was later confirmed by scholars such as Witt et al. (1998), Brush (2007), and Choe (2008). However, the background of theoretical studies on the causes and motivation to commit crime perhaps dates back to the works of Tullock (1967) and Becker (1968). Addressing the issue of robbery in monopoly, Tullock (1967) reported that robbery could lead to a reduction in resources investment due to the increase in welfare costs. In turn, Becker analyzed the rational behavior of criminals by presenting a theoretical model in purely economic analysis. In his view, criminals possessed rational behavior and they participated in criminal activities with profit-seeking incentives (Becker, 1968). According to Becker and Stigler (1974), and Akerlof and Dickens (1982), low wages by authorities had led to increased corruption, and paying decent wages was suggested as a solution to this problem (Akerlof \& Dickens, 1982; Becker \& Stigler, 1974). In a similar vein, Mauro (1995) examined the relationship between crime and economic growth rate. Likewise, Mauro (1995) and Wei (2000) evaluated the vulnerability of foreign direct investment and total investment resulting from corruption. Witte (1996), considered ghettos as important features of the US urban areas where an underground economy tended to flourish illegally in the social and economic life of people in the ghettos. Witte (1996) further noted that drugs and crime were linked as drugs were traded in an underground economy by organized gang members.

Similarly, Kaufmann (1997) argued that, with increasing economic corruption, production costs were likely to rise and that firms and companies tended to turn towards underground and illegal economic activities. By the same token, Tanzi and Davoudi (1998) maintained that corruption could lead to a decline in public sector budgets and structural productivity in the country. In another study, Aigner et al. (1988) showed a direct relationship between the increasing size of government and tendency towards smuggling. Moreover, there is also an reverse relationship between education and corruption (Treisman, 2000).

Aidt (2003) also investigated the relationship between an increase in social spending and a reduction in social welfare caused by corruption. In another study reported by Wang, Lin, and $\mathrm{Yu}$ (2006), a positive correlation was evident between the size of the underground economy and the logarithm of real government consumption and inflation rate. Their findings showed that crime rates and unemployment did not have any meaningful correlation with the underground economy. In describing the relationship between labor market variables and crime, Rickman and Witt (2007) considered personality traits and individual tendencies as effective in committing crime. In another study, Rose-Ackerman (2013) examined crime in terms of the political economy. The study discussed the connections between voters, legislators, interest groups, state bureaucracy, and corruption in the private sector, and also the relationship between corruption and democracy. Likewise, Cooter and Ulen (2016), examined crime in terms of expected profits; that is, if the final benefits of crime exceeds 
its expected final cost, the commission of the crime has an economic justification and, therefore, the crime happens.

The exact nature of the underground economy is not widely agreed upon. It is mainly composed of two types: criminal and non-criminal activities. As for criminal activities, diverse issues including illegal activities such as smuggling weapons, drugs, foreign exchange, illegal immigration, brand abuse, tax evasion, money laundering and corruption are involved. Similarly, empirical studies have shown that underground economic activities usually go hand in hand with crime and involve unpermitted medications, prostitution, money laundering and illegal gambling (Smith \& Christou, 2009). Smuggling, returned checks, corruption and drinking alcohol are some of the recognized types of criminal activities in Iran's punishment law. Primary studies on illegal economic activities in various sectors of Iran have indicated the importance and role of smuggling in Iran's economy. Seemingly, the tendency to violate laws such as tax, customs duties and social security expenses as well as disregarding rationing, quotas, standards and laws enforced by the government are among the most important features of hidden and underground activities in Iran's economy.

Thus, as most types of crime are closely related, this study is intended to examine the size and relationship between smuggling and crime indexes. To this end, this article is organized into four sections; after the introduction, definition of the underground economy is suggested in the second section. The research methods, model used and estimation of the parameters of the model are described in the third section. Results from examining the model of smuggling in Iran are analyzed in the fourth section.

\section{Literature Review}

Merton (1967) argued that crime and violence were directly related to the absence of opportunities for achieving social mobility through legitimate channels. Some other researchers postulated that criminal activities were no more than redistribution of wealth. For example, burglary and ransom kidnapping, which were bilateral or trilateral, involved the victim(s), perpetrator(s) and perhaps a middleman to dispose of the resulting merchandise or money. However, economically motivated crime involved the production and distribution of goods and services facilitated by the underground economy (Naylor, 1995). Naylor (1995) emphasized that crime and the underground economy were correlated at many levels. Likewise, Merton (1967) and Noguera (1996) surmised that crime and violence were not random phenomena, but rather followed more or less the same pattern. They further argued that the lack of economic opportunities in many impoverished urban communities created conditions that were conducive to the occurrence of crime and development of an underground economy (Merton, 1967; Noguera, 1996).

In a similar vein, Johnson et al. (1998) and Friedman et al. (2000) opined that the key determinants of underground activities were not tax rates, but rather the extent of regulatory discretion. It was believed that when regulations were laxed and the rule of law was weak, 
bureaucrats were allowed to make decisions on individual cases without supervision. This, in turn, created corruption in firms and companies (Friedman et al., 2000; Johnson et al., 1998). According to Glinkina (1999), due to the dissolution of the Soviet Union, underground economic relations developed above all; and long established links between separate industries and whole territories were disrupted, and borders between new states became permeable, presenting few obstacles to smuggling or other forms of criminal entrepreneurship.

Bate (2000) reported that revenue losses resulting from organized crime forced governments to cut down on expenses for public services, increased taxation or even ran deficits. In fact, Bate (2000) posited that smuggling was an important catalyst in stimulating the underground economy. In a similar vein, Schneider (2005) held that the shadow economy reduced corruption in high income countries, but the opposite was true for low income countries. Generally, there is wide range of theoretical and practical literature tackling the relationship between economic variables and smuggling using the MIMIC method (Albu, Iorgulescu, \& Stanica, 2010; Bajada \& Schneider, 2009; Dell'Anno, 2010; Dell'Anno \& Schneider, 2009; Dobre \& Alexandru, 2009; Schneider, 2015; Schneider \& Enste, 2000; Wang et al., 2006).

In the meantime, it was believed that those who were involved in smuggling-related activities preferred to conduct their transactions in cash. Therefore, by increasing the volume of smuggling, the demand for money in circulation was expected to increase. Accordingly, imposing more limitations on individuals could push them toward illegal trading, smuggling or submitting unreal statements to officials. Imposing extra import tariffs could also lead to under-representation of the value of imported goods, and therefore, trading of commodities illegally. Phylakits (1992) showed the positive effect of tariff obstacles on individuals' motivation to trade illegally. In fact, when trade limitations, frustrating regulations and tariff and non-tariff obstacles increased, individuals tended to perform illegal businesses. On the contrary, some other studies emphasized swift and refreshing openness to trade. However, without the efficient fulfillment of laws, corruption could increase (Phylaktis, 1991). Tanzi (1999) argued that the relationship between the rate of unemployment and shadow economy was vague. Therefore, the economic hypotheses cannot for certain reveal the relationship between the rate of unemployment and the shadow economy. Thus, such a probable relationship mainly depended on empirical analyses conducted in each country under investigation.

In turn, the misery index is, an economic indicator which is obtained by adding the rate of unemployment to the rate of inflation (Tanzi, 1999). Biswas and Marjit (2007) theoretically showed the relationship between the rate of foreign exchange in black markets and illegal trading. In effect, an increase in the price of consumer goods could also be considered as a causal factor in the size of smuggling. Moreover, an increase in inflation pushed more households below the poverty line and caused them to turn to smuggling. On the other hand, an increase in price led to a rise in the income of people and enterprises, which resulted in growth in their income tax payments. This, in turn, could lead to illegal activities in society. 
Considering the fact that the high rate of unemployment is one of the most crucial challenges in developing countries, studying its effects on smuggling is deemed significant. However, the influence of this variable on smuggling is vague (Biswas \& Marjit, 2007). According to Smith and Christou (2009), all economies which have aforementioned features are among the active economic markets. Based on this index, the underground economy is not defined as an illegal activity (Frey \& Weck-Hanneman, 1984), as it clearly includes trading and barter transactions (Schneider \& Enste, 2000; Zhuge et al., 2009). In contrast, Dellanno and Schneider (2009) reported a negative relationship between economic growth and underground economy.

Direct links between smuggling and crime have already been investigated in the literature; however, the current study was an attempt to examine different dimensions of moral crimes on direct and indirect trafficking. Thus, the main purpose of this research was to investigate the size and the relationship between smuggling and some crime indexes such as returned checks, corruption and drinking alcohol in Iran during the period between 1984 and 2015 by using MIMIC model and MLE method. More precisely, this research examined the mutual and hidden effects of moral and economic crimes in Iran.

\section{Definition of the Underground Economy}

According to Ogunc and Yilmaz (2000), there is no agreed upon concept for the underground economy in the literature. In many studies about the underground economy, expressions such as, unofficial, shadow, black, gray, hidden, unobserved, irregular and illegal economy have been used (Alderslade, Talmadge, \& Freeman, 2006; Ögünç \& Y1lmaz, 2000). Smith (1997) defined the underground economy as a market-based production which is not legally or illegally included in the official GNP calculations. In turn, Thomas (1999) divided the underground economy into four divisions and stated that on a large scale, the underground economy is related to all activities which are not included for any reason in national accounts.

Table 1

The structure of the underground economy from Thomas's viewpoint

\begin{tabular}{cccc}
\hline Section & Market transaction & Production form & The form of production/distribution \\
\hline Household & None & Legal & Legal \\
Unofficial & It has & Legal & Legal \\
Irregular & It has & Legal & Illegal \\
Illegal & It has & Illegal & Illegal \\
\hline
\end{tabular}

Source: Thomas, 1999 
He maintained that all these four sections are not similarly important in all countries and, most probably, the importance of these sections in every country differs as time marches on. Considering several studies such as Mirus, Smith and Program (1997); Mirus and Roger (1997) classified the underground economy as follows.

Table 2

The structure of underground economic activities from Mirus and Roger's viewpoint

\begin{tabular}{|c|c|c|c|c|}
\hline $\begin{array}{l}\text { Type of } \\
\text { activity }\end{array}$ & \multicolumn{2}{|l|}{ Monetary transaction } & \multicolumn{2}{|c|}{ Non-monetary transaction } \\
\hline \multirow[t]{2}{*}{ Illegal } & \multicolumn{2}{|c|}{$\begin{array}{l}\text { Trading stolen commodities, producing and } \\
\text { trans-activating unpermitted medication, } \\
\text { smuggling, prostitution, money laundering, } \\
\text { gambling, fraud, forgery, hacking computer } \\
\text { systems, trading information, identity robbery }\end{array}$} & \multicolumn{2}{|c|}{$\begin{array}{l}\text { Barter transaction of medication, } \\
\text { production of medication, } \\
\text { robbery, smuggling for personal } \\
\text { consumption }\end{array}$} \\
\hline & Tax evasion & $\begin{array}{c}\text { Tax } \\
\text { avoidance }\end{array}$ & Tax evasion & $\begin{array}{c}\text { Tax } \\
\text { avoidance }\end{array}$ \\
\hline Legal & $\begin{array}{l}\text { Unreported income earned from } \\
\text { working, wage, wealth interest, } \\
\text { and unreported properties, } \\
\text { personal commodity and services }\end{array}$ & $\begin{array}{l}\text { Work } \\
\text { discount } \\
\text { and job } \\
\text { advantages }\end{array}$ & $\begin{array}{l}\text { Barter transaction } \\
\text { of legal } \\
\text { commodity and } \\
\text { services }\end{array}$ & $\begin{array}{l}\text { Whatever a } \\
\text { person does } \\
\text { for himself } \\
\text { and his } \\
\text { relatives }\end{array}$ \\
\hline
\end{tabular}

Source: Mirus and Roger (1997)

Similarly, Feige and Ott (1999) categorized the underground economy into four types: illegal, unreported, unregistered and unofficial.

ILLEGAL: All income which is earned through illegal activities and tax evasion. Activities include transaction of unpermitted medication, smuggling, prostitution, money laundering, and gambling.

UNREPORTED: All economic activities which are provided for economic and noneconomic resources in order to evade or avoid financial regimes.

UNREGISTERED: All activities needed but not registered for economic policies.

UNOFFICIAL: Economic activities which earn profit for owners through an intermediation process without any expenses.

Marinov (2008) defined the underground economy in three sections: unofficial, shadow and black economy. 
Table 3

The structure of underground economic activities from Marinov's viewpoint

\begin{tabular}{cll}
\hline Section & \multicolumn{1}{c}{ Activity } & \multicolumn{1}{c}{ Explanation } \\
\hline Unofficial & $\begin{array}{l}\text { Legal but unofficial } \\
\text { activities }\end{array}$ & Personal production or transactions \\
Legal and uncustomary & $\begin{array}{l}\text { 1-non registered businesses and hidden income } \\
\text { activities }\end{array}$ & $\begin{array}{l}\text { 2-illegal activities in lawful form } \\
\text { Trading of stolen commodities, producing and } \\
\text { transacting unpermitted medication, smuggling }\end{array}$ \\
\hline
\end{tabular}

Source: Marinov, 2008.

\section{Multiple Indicators Multiple Causes}

Structure equations model (SEM) shows the relationship between unobserved and observed variables and is extensively applied in many fields of social science including sociology, marketing and economics. In economics, one of the first studies about the applications of SEM was carried out by Goldberg in which a special form of SEM, namely multiple-indicators multiple-causes was applied. Multiple Indicators Multiple Causes (MIMIC) models are often employed by researchers studying the effects of an unobservable latent variable on a set of outcomes, where causes of the latent variable are observed. There are times, however, when the causes of the latent variable are not observed because measurements of the causal variable are contaminated by measurement errors. Generally, the MIMIC model has two main parts, namely structural equation and measuring equation. The structural equation corresponding to a series of observable indexes is as follows:

(1) $Y_{i}=\lambda_{i} \eta+u_{i}$

In which $Y_{i}$ shows the observed index in the underground economy, $\eta$ is equated with hidden variables, $u_{i}$ shows accidental error and $\lambda_{i}$ shows the structure parameters of the measuring model. In this formula, the measuring equation is defined as follows:

(2) $\eta=\gamma_{1} x_{1}+\gamma_{2} x_{2}+\ldots+\gamma_{p} x_{p}+v$

In which $x_{p}(\mathrm{i}=1,2, \ldots, \mathrm{p})$ indicates a series of casual observed variables such as the rate of unemployment, the rate of inflation, and the rate of real tariffs, $\gamma_{p}(\mathrm{i}=1,2, \ldots, \mathrm{p})$ which reflects the structural parameters of the model, $V$ error term and $\eta$ stands for hidden variable (i.e., smuggling ). Equations 1 and 2 can be rewritten as follows: 
(3) $Y=\lambda \eta+v$

(4) $\eta=\gamma x+v$

It is assumed that there is no correlation between the error term of the third and fourth equation.

(5) $E(u v)=0, E\left(v^{2}\right)=\sigma^{2}, E\left(u^{\prime} u\right)=\theta^{2}$

In order to reach a function of the observed variables, equation 3 can be fitted into equation 4 :

(6) $Y=(\gamma x+v) \lambda+v$

By defining $y l={ }^{\prime}, w=l v+u$ equation 6 can be rewritten as follows. In this case a modified form of the MIMIC model can be reached:

(7) $Y=\prod x+w$

On this basis, the conceptual MIMIC model can be shown as follows:

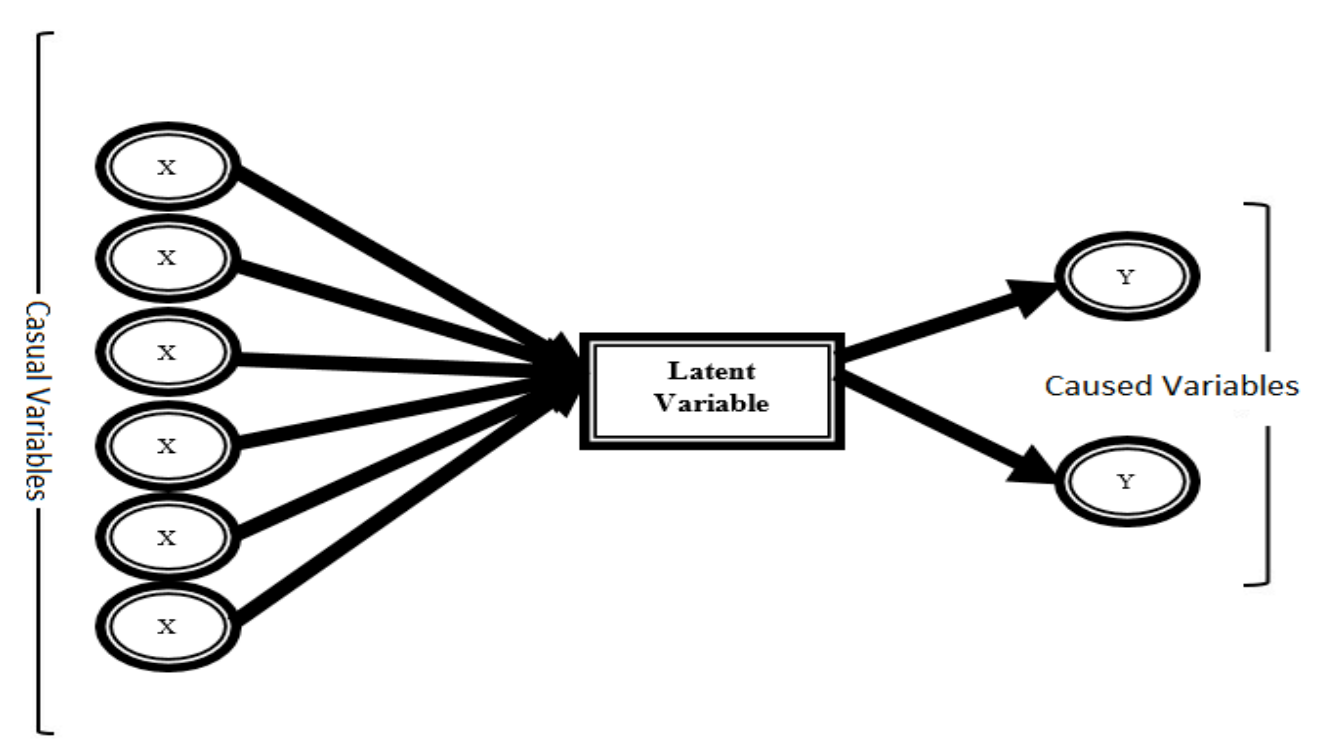

Figure 1. The Conceptual MIMIC Model

Source: Joreskog and Goldberger, 1975

In this research, the data for variables such as returned checks, divorce, corruption, and drinking alcohol were taken from the Statistics and Information Technology Center of Judicial system of Iran. These data included closed cases in public trials. On the other 
hand, economic data and statistics on imports (constant prices indicated in Rials), tax on imports (constant prices in Rials), government expenditures (constant prices in Rials), gross domestic product (GDP) (constant prices in Rials), bilateral official and unofficial exchange rates of Rials to US dollars, illiteracy rate (percentage), energy consumption (constant prices in Rials), unemployment rate (percentage), inflation (percentage), liquidity (M1 and M2 constant prices in Rials) were derived from the Central Bank of Iran and the Statistics Center of Iran. In order to use such data and statistics for the purpose of this research, the variables used in the estimation are defined as follows:

\section{Crime variables}

- $\quad$ Returned checks: Returned checks due to fraud or lack of liquidity are considered as crime in Iranian law and are subjected to a sentence of imprisonment from six months to two years. Returned checks (C1) as the growth rate of the number of closed cases in public trials was considered as a cause variable for smuggling.

- Corruption: In this study, corruption includes embezzlement, bribery and forgery. Generally based on the above definitions, the variable on corruption (C3) as the growth rate of the number of closed cases in public trials was classified as a cause variable for smuggling.

- Drinking alcohol: As many alcoholic beverages are considered as unpermitted commodities in Iranian law, a lot of these goods are imported illegally through smuggling. The variable of drinking alcohol (C4) as the growth rate of the number of closed cases in public trials was defined as a causal variable for smuggling.

\section{Social variables}

- Divorce: Although divorce is not considered as a social crime, it is classified as a causal variable for smuggling, because it leads to many social disorders for both couples and children. This variable is shown as $\mathrm{C} 2$ representing the growth rate of the number of closed cases in public trials.

- Education: In this study, the rate of illiteracy (percentage) was used in order to reveal the effects of education on smuggling, and a positive relationship between smuggling and the rate of illiteracy was expected. This variable is shown as ILI.

- Poverty index: The misery index to percentage (inflation plus unemployment) as a poverty index is a criterion to show the economic and social circumstances of countries. This variable is shown as MI.

\section{Economic variables}

The index of economic openness: In order to calculate the index of economic openness, two indexes were used:

- The growth rate of the proportion of imports to GDP, referred to as OME.

- The growth rate of tax on imports, referred to as NTM. 
- Foreign exchange market changes: Changes in foreign exchange markets can be also considered as an important factor for the expansion of illegal activities. The rate of foreign exchange is highly changeable in Iran. In this study, we considered the rate of foreign exchange in official and unofficial markets as the cause variables for smuggling. In effect, the growth rate of the gap between the rate of exchange in the official and unofficial (DEX) markets was considered and a positive relationship with smuggling was expected.

- The size of government: The growth rate of the proportion of government expenditure on GDP was used as the variable for government size and referred to as GG.

- Money demand: The growth of liquidity (M) was used as an index to show the effects of smuggling.

- The consumption of oil products: Consuming oil products and granting remarkable subsidies to oil products has lowered the market price of oil products in Iran compared to its neighboring countries like Iraq, Afghanistan and Pakistan, leading to an increasing tendency to smuggle oil products to these countries. For this reason, smuggling was expected to have a positive effect on the consumption of oil products in Iran. The growth in consumption of oil products is referred to as CE.

On this basis, the conceptual model of commodity smuggling in Iran can be shown as follows:

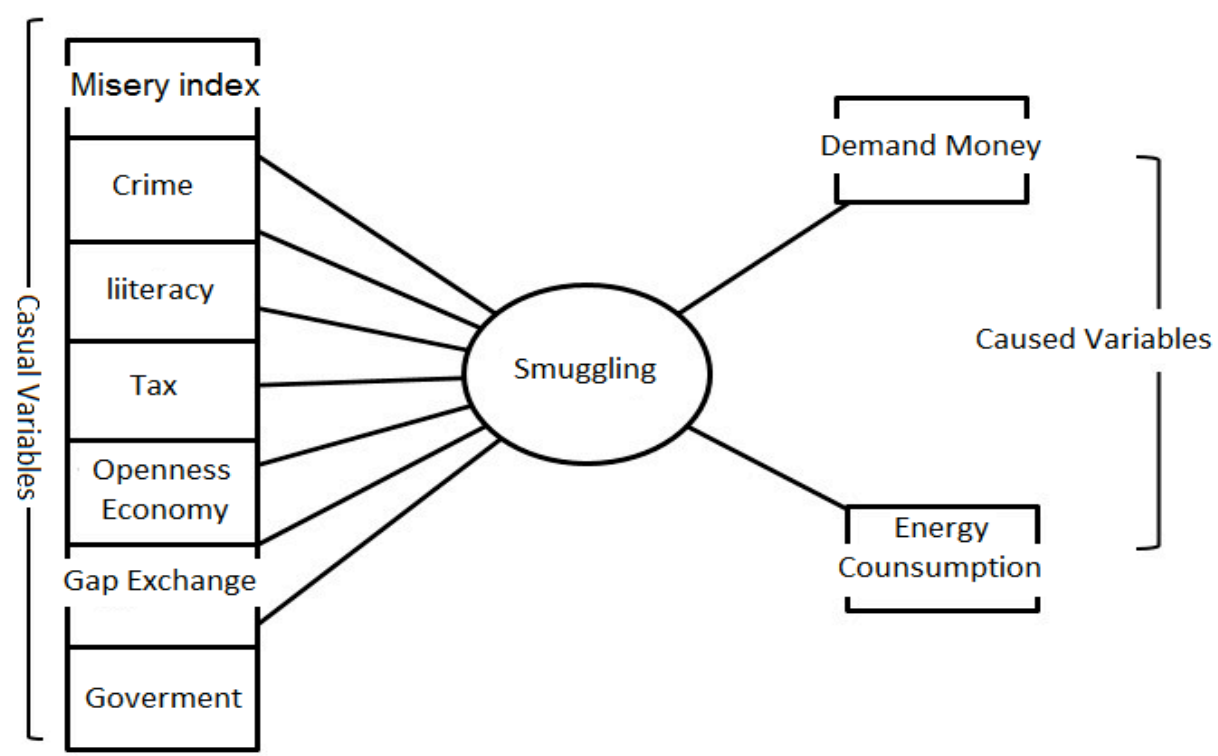

Figure 2. Conceptual Model of Smuggling Framework in Iran based on MIMIC Model

Source: Research result 


\section{The Results of Stationary Test of Variables}

The MIMIC model is invalid in the absence of doing a unit root stationary test of variables. Thus, a stationary state of variables was tested using Augmented Dicky-Fuller (ADF) method and EVIEWS7 software package. Akaike Information Criteria (AIC) was also used to determine the length of optimal lag. The tested relationship in this study was carried out based on such types of relationship: none, with intercept and with intercept and trend. The results of the stationary test are shown in Table 4. As can be seen in Table 4, the variables are not unit root.

Table 4

Results of stationary test

\begin{tabular}{ccc}
\hline Variable & Statistic & Critical Value $(0.05)$ \\
\hline C1 & -2.5 & -1.96 \\
C2 & -3.1 & -2.98 \\
C3 & -4.8 & -2.98 \\
C4 & -4.7 & -2.98 \\
NTM & -5.4 & -2.98 \\
MI & -6.3 & -2.98 \\
ILI & -5.4 & -2.98 \\
DEX & -3.8 & -2.98 \\
OME & -7.0 & -2.98 \\
GG & -6.3 & -2.98 \\
CE & -4.5 & -2.98 \\
M & -4.5 & -2.98 \\
\hline
\end{tabular}

Source: Research results

\section{The results of Model Estimation}

The estimation of smuggling was conducted using Lisre19.1 and MLE method. In finding a model of structural equations, the aim was to select the best model based on statistical significance of theory. For this reason, in the framework of research methodology, more than 100 models were surveyed and tested. In order to select a superior model, two methods were applied. Based on Frey and Weck-Hannemann's method (1984), in choosing the superior method, compliance with theoretical foundations and significant symptoms of variable 
coefficients were prioritized. However, in Giles's method (1999), the general estimation of the method was of higher priority. On this basis, Table 5 shows the results of estimating superior model coefficients of smuggling.

Table 5

Results of model selection

\begin{tabular}{|c|c|c|c|c|c|}
\hline Model & 1 & 2 & 3 & 4 & 5 \\
\hline \multicolumn{6}{|c|}{ Caused } \\
\hline $\begin{array}{c}\mathrm{CE} \\
\text { (P-value) }\end{array}$ & $\begin{array}{c}0.03 \\
(0.00)\end{array}$ & $\begin{array}{c}0.03 \\
(0.00)\end{array}$ & $\begin{array}{c}0.03 \\
(0.00)\end{array}$ & $\begin{array}{c}0.03 \\
(0.00)\end{array}$ & $\begin{array}{c}0.03 \\
(0.00)\end{array}$ \\
\hline $\begin{array}{c}\mathrm{M} \\
(\mathrm{P}-\text { value })\end{array}$ & $\begin{array}{c}0.11 \\
(0.00)\end{array}$ & $\begin{array}{c}0.12 \\
(0.01)\end{array}$ & $\begin{array}{l}0.12 \\
(0.1)\end{array}$ & $\begin{array}{c}0.09 \\
(0.01)\end{array}$ & $\begin{array}{l}0.095 \\
(0.01)\end{array}$ \\
\hline \multicolumn{6}{|c|}{ Casual } \\
\hline $\begin{array}{c}\mathrm{C} 1 \\
\text { (P-value) }\end{array}$ & $\begin{array}{l}-0.023 \\
(0.02)\end{array}$ & $\begin{array}{l}-0.021 \\
(0.02)\end{array}$ & $\begin{array}{l}-0.02 \\
(0.02)\end{array}$ & $\begin{array}{c}-0.07 \\
(0.03)\end{array}$ & $\begin{array}{l}-0.026 \\
(0.02)\end{array}$ \\
\hline $\begin{array}{c}\mathrm{C} 2 \\
\text { (P-value) }\end{array}$ & $\begin{array}{l}0.065 \\
(0.03)\end{array}$ & $\begin{array}{l}0.053 \\
(0.05)\end{array}$ & $\begin{array}{l}0.054 \\
(0.05)\end{array}$ & $\begin{array}{r}0.065 \\
(0.1)\end{array}$ & $\begin{array}{l}0.062 \\
(0.06)\end{array}$ \\
\hline $\begin{array}{c}\text { C3 } \\
\text { (P-value) }\end{array}$ & $\begin{array}{c}0.03 \\
(0.09)\end{array}$ & $\begin{array}{l}0.03 \\
(0.07)\end{array}$ & $\begin{array}{l}0.04 \\
(0.06)\end{array}$ & $\begin{array}{c}-0.006 \\
(0.8)\end{array}$ & $\begin{array}{l}0.042 \\
(0.06)\end{array}$ \\
\hline $\begin{array}{c}\mathrm{C} 4 \\
\text { (P-value) }\end{array}$ & $\begin{array}{l}0.007 \\
(0.06)\end{array}$ & $\begin{array}{l}0.006 \\
(0.07)\end{array}$ & $\begin{array}{l}0.004 \\
(0.08)\end{array}$ & $\begin{array}{l}0.028 \\
(0.03)\end{array}$ & $\begin{array}{l}0.012 \\
(0.06)\end{array}$ \\
\hline $\begin{array}{c}\text { NTM } \\
\text { (P-value) }\end{array}$ & & & & $\begin{array}{l}0.014 \\
(0.04)\end{array}$ & $\begin{array}{l}0.006 \\
(0.06)\end{array}$ \\
\hline $\begin{array}{c}\text { MI } \\
\text { (P-value) }\end{array}$ & $\begin{array}{c}0.24 \\
(0.01)\end{array}$ & $\begin{array}{l}0.24 \\
(0.01)\end{array}$ & $\begin{array}{l}0.25 \\
(0.01)\end{array}$ & & $\begin{array}{c}0.29 \\
(0.01)\end{array}$ \\
\hline $\begin{array}{c}\text { ILI } \\
\text { (P-value) }\end{array}$ & $\begin{array}{l}0.087 \\
(0.02)\end{array}$ & $\begin{array}{l}0.081 \\
(0.02)\end{array}$ & & $\begin{array}{c}0.22 \\
(0.06)\end{array}$ & $\begin{array}{c}0.1 \\
(0.02)\end{array}$ \\
\hline $\begin{array}{c}\text { DEX } \\
\text { (P-value) }\end{array}$ & $\begin{array}{l}0.001 \\
(0.02)\end{array}$ & $\begin{array}{l}0.001 \\
(0.03)\end{array}$ & $\begin{array}{l}0.001 \\
(0.03)\end{array}$ & $\begin{array}{l}0.001 \\
(0.07)\end{array}$ & $\begin{array}{l}0.001 \\
(0.04)\end{array}$ \\
\hline $\begin{array}{c}\text { OME } \\
\text { (P-value) }\end{array}$ & $\begin{array}{l}0.033 \\
(0.01)\end{array}$ & $\begin{array}{l}0.03 \\
(0.01)\end{array}$ & $\begin{array}{l}0.026 \\
(0.02)\end{array}$ & $\begin{array}{l}0.05 \\
(0.02)\end{array}$ & $\begin{array}{l}0.032 \\
(0.02)\end{array}$ \\
\hline $\begin{array}{c}\text { GG } \\
\text { (P-value) }\end{array}$ & & $\begin{array}{l}0.045 \\
(0.02)\end{array}$ & $\begin{array}{l}0.044 \\
(0.02)\end{array}$ & $\begin{array}{l}0.073 \\
(0.03)\end{array}$ & $\begin{array}{l}0.065 \\
(0.02)\end{array}$ \\
\hline
\end{tabular}

Source: Research results 
Results from Table 5 can be summarized as follows:

1. In all superior models, the variables of divorce and drinking alcohol were positively correlated with smuggling, but the reverse was true for returned checks.

2. All macroeconomic variables affecting smuggling including tax on imports, misery index, illiteracy, the gap between official and unofficial exchange rates, the index of openness economy and government size led to an increase in smuggling.

3. All variables affected by smuggling including liquidity and energy consumption had a positive relationship with smuggling.

4. Divorce and misery index were the most effective variables on smuggling.

To select the final model, first, models showing acceptable indexes of smuggling were chosen. Then, the model which had the best status according to the Lisrel criteria was selected as the superior model. Table 6 shows the Lisrel general estimate criteria for superior models.

Table 6

Criteria for assessing estimated models

\begin{tabular}{ccccccc}
\hline Index & $\mathrm{R}^{2}$ & $\chi^{2}$ & $\mathrm{RMSE}^{1}$ & $\mathrm{NNFI}^{2}$ & $\mathrm{CFI}^{3}$ & $\mathrm{AGFI}^{4}$ \\
\hline 1 & 0.88 & 1.2 & 0 & 1.6 & 1 & 0.95 \\
2 & 0.84 & 3.4 & 0 & 1.5 & 1 & 0.87 \\
3 & 0.8 & 3.4 & 0 & 1.4 & 1 & 0.86 \\
4 & 0.61 & 6.8 & 0 & 1.2 & 1 & 0.79 \\
5 & 0.87 & 7.1 & 0 & 1.2 & 1 & 0.75 \\
\hline
\end{tabular}

Source: Research results

The quantitative results in Table 6 reveal that all models possessed proper status according to the general assessment criteria of Lisrel. However, their comparison suggests model 1 as the superior model. As variables were used with growth trend, the index of smuggling was calculated as the growth of smuggling. Figure 3 illustrates the growth trend in smuggling in Iran during 1984-2015.

\footnotetext{
${ }^{1}$ Root Mean Square Error of Approximation

${ }^{2}$ Non-Normed Fit Index

${ }^{3}$ Comparative Fit Index

${ }^{4}$ Adjusted Goodness of Fit Index
} 


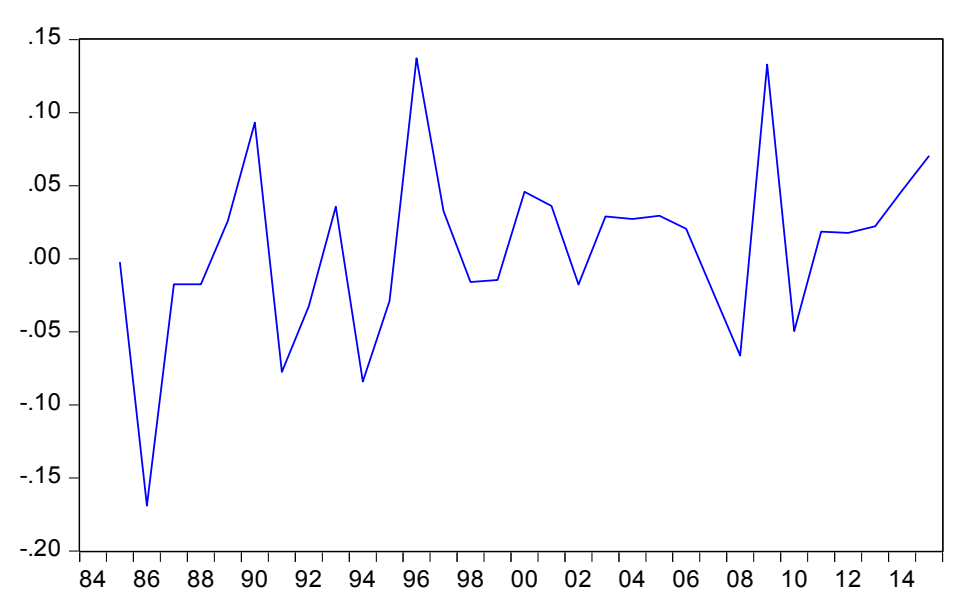

Figure 3. Trends in growth of smuggling in Iran (1984-2015)

Source: Research result

Figure 3 shows the minimum growth of smuggling is $-16.9 \%$ in 1986 and the maximum growth is $13 \%$ in 1996 and 2009 . To calculate the relative size of smuggling in terms of the percentage of GDP in Iran, six previous empirical research studies were used. The trend in the volume of smuggling based on the base year of 1997 and also the growth of smuggling are shown in Figure 4 as follows.

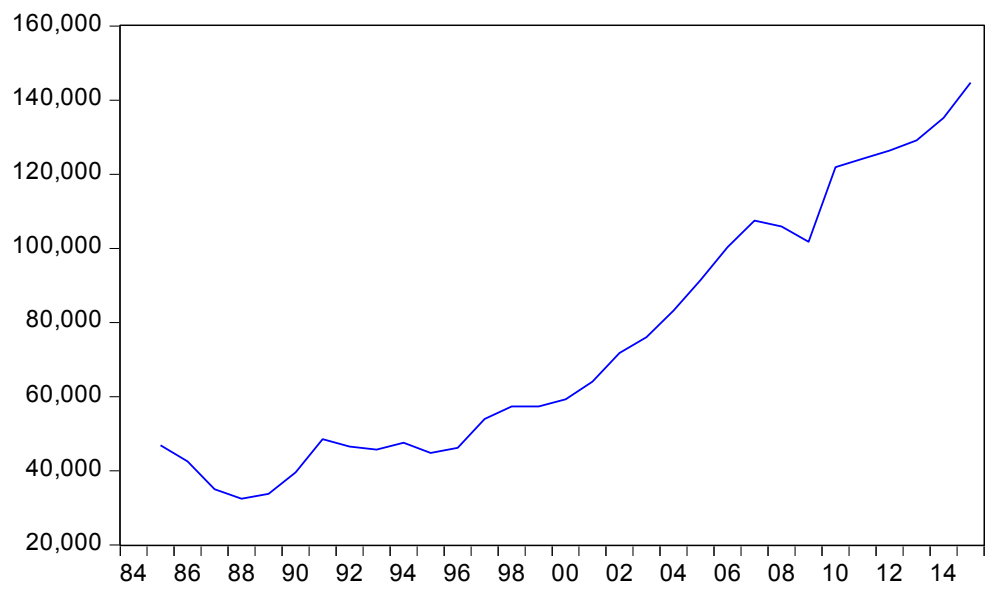

Figure 4. Absolute trend of smuggling in Iran (1984-2015) 
Figure 4 reveals that the volume of smuggling during the period of study was upward, although with a fluctuating trend. The relative index of smuggling (a percentage of GDP) is shown in Figure 5 as follows.

Based on Figure 5, the relative volume of smuggling (a percentage of GDP) starts from $22 \%$ in 1985 and shows a downward trend to reach its minimum level of $16 \%$ in 1996. After this decline in 1996 , it fluctuates to peak at $27 \%$ in 2015 . The results of the study revealed that the volume of smuggling in Iran in the study period was $19.5 \%$ of GDP, on average.

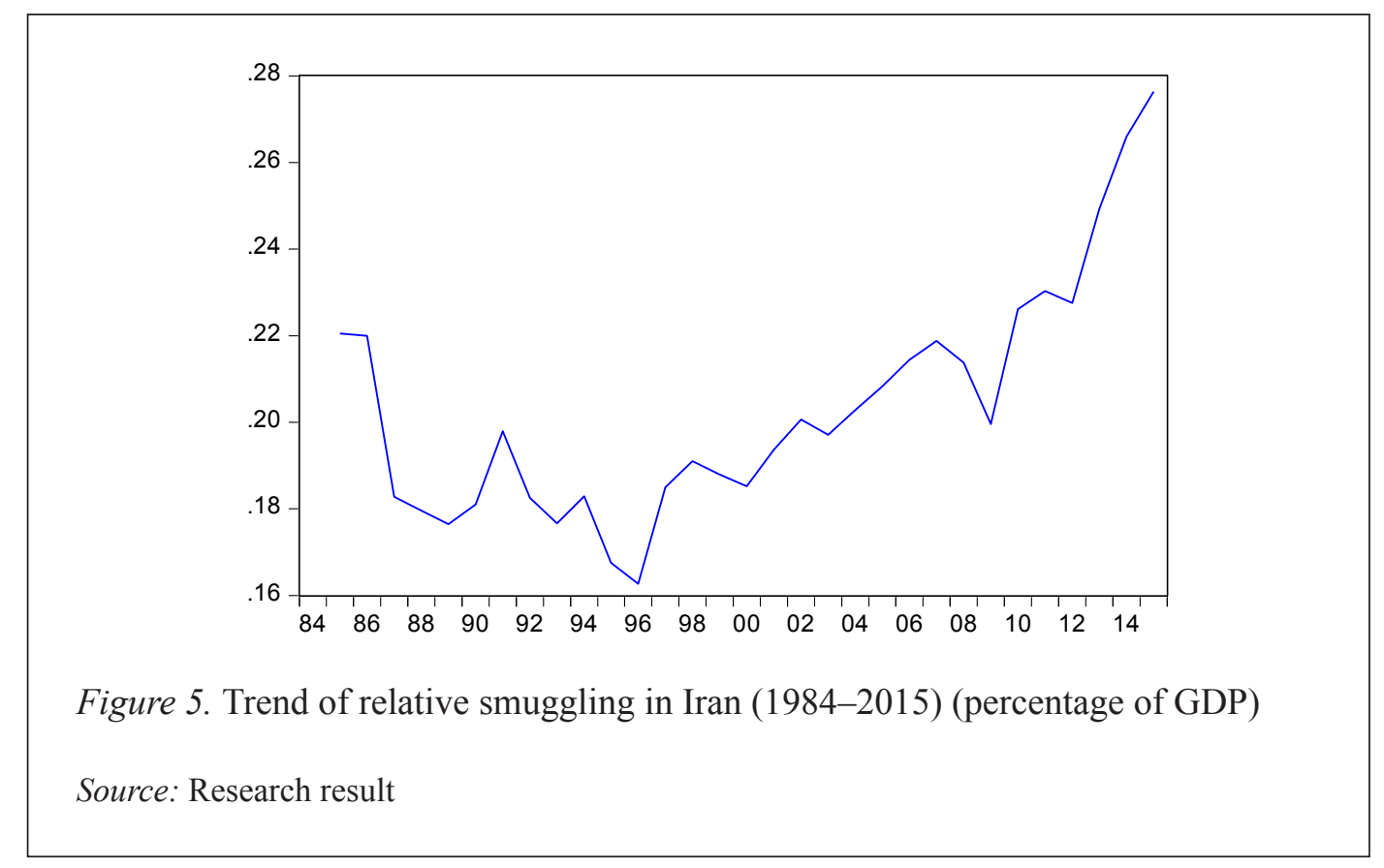

\section{Conclusion}

This research was intended to calculate the size of smuggling and its relationship with some crime indexes in Iran during the period between 1984 and 2015 using the MIMIC model. The estimation of smuggling was carried out through the software package of Lisrel9.1 and the MLE method. For the purpose of research, more than 100 models were surveyed and tested. The results showed that among all superior indexes of crime variables, divorce, corruption and drinking alcohol were positively correlated with smuggling, while returned checks had a negative impact on smuggling. These results are consistent with those of Smith and Christou (2009), Merton (1967) and Noguera (1996). Furthermore, all macroeconomic variables affecting smuggling including tariffs on imports, misery index, illiteracy, gap of exchange rate, index of openness of economy and the size of government increased smuggling. This finding is supported by results from Aigner et al. (1988), Friedman et al. 
(2000), Schneider (2005) and Wang et al. (2006). Moreover, variables affected by smuggling including liquidity and energy consumption were found to be positively correlated with smuggling. This finding is in line with the findings by Albu et al. (2010), Bajada and Schneider (2009), Dobre and Alexandru (2009), Schneider (2015), Schneider and Enste (2000) and Wang et al. (2006). Likewise, divorce and misery indexes were the most effective variables on smuggling. Besides, studying the growth trend of smuggling in Iran revealed that the minimum growth of smuggling was $-16.9 \%$ in 1987 , while the maximum growth was $13 \%$ in 1996 and 2009. It was also found that the relative volume of smuggling (a percentage of GDP) reached from $22 \%$ in 1984 to its lowest volume of $16 \%$ in 1996, and it went up to peak at $23 \%$ in 2015 . Although studying the volume of smuggling in Iran followed a fluctuating trend, this trend was found to be an upward one. Finally, the results of this study revealed that the average amount of smuggling in the research period in Iran constituted $19.5 \%$ of its GDP.

\section{References}

Aidt, T. S. (2003). Economic analysis of corruption: A survey. The Economic Journal, 113(491), F632-F652.

Aigner, D. J., Schneider, F., \& Ghosh, D. (1988). Me and my shadow: Estimating the size of the U.S. hidden economy from time series data. In E. R. Berndt, H. White, \& W. A. Barnett (Eds.), Dynamic Econometric Modeling: Proceedings of the Third International Symposium in Economic Theory and Econometrics (pp. 297-334). Cambridge: Cambridge University Press.

Akerlof, G. A., \& Dickens, W. T. (1982). The economic consequences of cognitive dissonance. The American Economic Review, 72(3), 307-319.

Albu, L.-L., Iorgulescu, R., \& Stanica, C. (2010). Estimating hidden economy and hidden migration: The case of Romania. Romanian Journal of Economic Forecasting, 2(13), 46-56.

Alderslade, J., Talmadge, J., \& Freeman, Y. (2006). Measuring the informal economy: One neighborhood at a time. Citeseer.

Bajada, C., \& Schneider, F. (2009). Unemployment and the shadow economy in the OECD. Revue économique, 60(5), 1033-1067.

Bate, R. (2000). Smuggling-the unintended consequence of government intervention. October, 11, 11.

Becker, G. S. (1968). Crime and punishment: An economic approach. The economic dimensions of crime (pp. 13-68). Springer.

Becker, G. S., \& Stigler, G. J. (1974). Law enforcement, malfeasance, and compensation of enforcers. The Journal of Legal Studies, 3(1), 1-18.

Biswas, A. K., \& Marjit, S. (2007). Preferential trade and mis-invoicing: Some analytical implications. International Review of Economics \& Finance, 16(1), 130-138.

Cooter, R., \& Ulen, T. (2016). Law and economics. Addison-Wesley.

Dell'Anno, R. (2010). Institutions and human development in the Latin American informal economy. Constitutional Political Economy, 21(3), 207-230. 
Dell'Anno, R., \& Schneider, F. (2009). A complex approach to estimate shadow economy: The structural equation modelling. Coping with the Complexity of Economics (pp. 111-130). Springer.

Dobre, I., \& Alexandru, A. (2009). Estimating the size of the shadow economy in Japan: A structural model with latent variables. Economic Computation and Economic Cybernetics Studies and Research, 43(1), 67-82.

Feige, E. L., \& Ott, K. (1999). Underground Economies in Transition: Unrecorded Activity, Tax Evasion, Corruption, and Organized Crime. Ashgate.

Fleisher, B. M. (1963). The effect of unemployment on juvenile delinquency. Journal of Political Economy, 71(6), 543-555.

Frey, B. S., \& Weck-Hanneman, H. (1984). The hidden economy as an 'unobserved' variable. European Economic Review, 26(1-2), 33-53.

Friedman, E., Johnson, S., Kaufmann, D., \& Zoido-Lobaton, P. (2000). Dodging the grabbing hand: The determinants of unofficial activity in 69 countries. Journal of Public Economics, 76(3), 459-493.

Giles, D. E. (1999). Modelling the hidden economy and the tax-gap in New Zealand. Empirical Economics, 24(4), 621-640.

Glinkina, S. (1999). Russia's underground economy during the transition. Underground Economies in Transition: Unrecorded Activity, Tax Evasion, Corruption and Organized Crime, 43-63.

Johnson, S., Kaufmann, D., \& Zoido-Lobaton, P. (1998). Regulatory discretion and the unofficial economy. The American Economic Review, 88(2), 387-392.

Jöreskog, K. G., \& Goldberger, A. S. (1975). Estimation of a model with multiple indicators and multiple causes of a single latent variable. Journal of the American Statistical Association, 70(351a), 631-639.

Kaufmann, D. (1997). Corruption: the facts. FOREIGN POLICY-WASHINGTON-, 114131.

Marinov, A. (2008). Hidden economy in the rural regions of Bulgaria. International Review on Public and Nonprofit Marketing, 5(1), 71-80.

Mauro, P. (1995). Corruption and growth. The Quarterly Journal of Economics, 110(3), 681-712.

Merton, R. K. (1967). On theoretical sociology. New York: Free Press.

Mirus, R., Smith, R. S., \& Program, H. L. S. I. T. (1997). Self-employment, Tax Evasion, and the Underground Economy: Micro-based Estimates for Canada: International Tax Program, Harvard Law School.

Naylor, R. T. (1995). From underworld to underground. Crime, Law and Social Change, 24(2), 79-150.

Noguera, P. A. (1996). Violence Prevention and the Latin Population. Motion Magazine, $22,2-5$.

Öğünç, F., \& Y1lmaz, G. (2000). Estimating the underground economy in Turkey. CBRT Research Department Discussion Paper, 15.

Phylaktis, K. (1991). The black market for dollars in Chile. Journal of Development Economics, 37(1-2), 155-172. 
Rickman, N., \& Witt, R. (2007). The determinants of employee crime in the UK. Economica, 74(293), 161-175.

Rose-Ackerman, S. (2013). Corruption: A Study in Political Economy. Elsevier Science.

Schneider, F. (2005). Shadow economies of 145 countries all over the world: What do we really know. Retrieved from

Schneider, F. (2015). Size and development of the shadow economy of 31 European and 5 other OECD countries from 2003 to 2014: Different developments? Journal of SelfGovernance and Management Economics, 3(4), 7-29.

Schneider, F., \& Enste, D. H. (2000). Shadow economies: Size, causes, and consequences. Journal of Economic Literature, 38(1), 77-114.

Smith, P. M. (1997). Assessing the size of the underground economy: The statistics Canada perspective. The underground economy: Global evidence of its size and impact, 11-37.

Smith, R., \& Christou, M. L. (2009). Extracting value from their environment: Some observations on pimping and prostitution as entrepreneurship. Journal of Small Business \& Entrepreneurship, 22(1), 69-84.

Tanzi, V. (1999). Uses and abuses of estimates of the underground economy. The Economic Journal, 109(456), 338-347.

Tanzi, V., \& Davoodi, H. (1998). Corruption, public investment, and growth The welfare state, public investment, and growth (pp. 41-60). Springer.

Thomas, J. (1999). Quantifying the black economy:'Measurement without theory' yet again? The Economic Journal, 109(456), 381-389.

Treisman, D. (2000). The causes of corruption: A cross-national study. Journal of Public Economics, 76(3), 399-457.

Tullock, G. (1967). The welfare costs of tariffs, monopolies, and theft. Economic Inquiry, 5(3), 224-232.

Wang, D. H.-M., Lin, J.-Y., \& Yu, T. H.-K. (2006). A MIMIC approach to modeling the underground economy in Taiwan. Physica A: Statistical Mechanics and its Applications, 371(2), 536-542.

Wei, S.-J. (2000). How taxing is corruption on international investors? Review of Economics and Statistics, $82(1), 1-11$.

Witte, A. D. (1996). Urban crime: Issues and policies. Housing Policy Debate, 7(4), 731748.

Zhuge, J., Holz, T., Song, C., Guo, J., Han, X., \& Zou, W. (2009). Studying malicious websites and the underground economy on the Chinese web. Managing information risk and the economics of security (pp. 225-244). Springer. 